\section{Peri-Implant Bone Loss of External Hexagon and Morse Taper in Patients Wearing Immediately Loaded Overdentures}

Laércio Almeida de Melo', Mariana Barbosa Câmara de Souzaㄹ, Gustavo Augusto Seabra Barbosa ${ }^{1}$, Adriana da Fonte Porto Carreiro ${ }^{1}$

\author{
'Department of Dentistry, UFRN - \\ Universidade Federal do Rio Grande \\ do Norte, Natal, RN, Brazil \\ 2Piracicaba Dental School, \\ UNICAMP - Universidade Estadual \\ de Campinas, Piracicaba, SP, Brazil \\ Correspondence: Dr. Laércio Almeida \\ de Melo, Av. Salgado Filho, 1787, \\ Lagoa Nova, 59056-000 Natal, RN, \\ Brasil. Tel: +55-84-3215-4100. e-mail: \\ laercio_melo91@hotmail.com
}

The aim of this study was to evaluate the peri-implant bone loss of External Hexagon (EH) and Morse Taper (MT) implants in patients wearing immediately loaded mandibular overdentures during a 1-year follow-up. This is a non-randomized controlled clinical trial including 18 MT and 22 EH implants. Periapical radiographs were taken after overdentures insertion and following 1 year. The peri-implant bone loss was assessed through digitalization and analysis of the radiographs in the software Corel DRAW X7. For this, measurement from implant platform to residual ridge at mesial and distal surfaces of each implant was conducted. The results showed high success rate in the groups EH $(100 \%)$ and MT (94.4\%). For peri-implant bone levels, it was found significant difference between the groups ( $p=0.032)$ and greater bone loss was observed in the group EH. In general, bone loss was $0.85 \mathrm{~mm}( \pm 0.82)$ for $\mathrm{EH}$ and $0.10 \mathrm{~mm}( \pm 1.0)$ for MT. It was concluded that greater bone loss occurred in the group EH in comparison to the group MT after a 1-year follow-up.

\author{
Key Words: dental implants. \\ osseintegration. peri- \\ implantitis. implant-supported \\ fixed dental prosthesis.
}

\section{Introduction}

Implant-supported mandibular overdentures have become an efficient treatment for complete edentulous patients reporting problems with their conventional dentures (1). This restoration design is associated with proper stability and retention, satisfactory chewing performance, improved quality of life and good esthetics $(2,3)$. In order to simplify the restoration process in timely manner, the dental implants and prosthesis can be inserted in a single step (4). These immediately loaded mandibular overdentures present high success rates, regardless the implant joint design used (5). However, the restoration under immediate load has been reported as one of the etiological factors for peri-implant bone loss $(5,6)$.

The longevity of implant-supported overdentures is crucial for long-term success of implants, which depends on health of peri-implant tissues for maintenance of maxillary bone (7). The marginal bone level around the implants is an important criterion to be evaluated about peri-implant success (8). The platform design is another relevant feature for biomechanical and esthetic success of this restoration (9). In external joints, microgaps between the implant and abutment are found, in contrast to the implants with tapered internal joint; such as Morse Taper, which exhibits intimate matching between the components $(9,10)$. This accurate fit provides better sealing against bacterial microleakage between the implant and abutment, preserving the peri-implant tissues (9).
Considering the findings of clinical and laboratorial trials and studies in animals evaluating the impact of platform design on bone loss, it can be concluded that there is a lack of data in the literature provided by a reduced number of studies (11). Furthermore, those studies do not standardize the implant-supported prosthesis design and the protocol of immediate loading or conventional loading (12-14).

Thus, considering the relevance of evaluating periimplant health for long-term success of implants, the aim of this study was to assess the peri-implant bone loss and success rate of External Hexagon and Morse Taper implants in patients wearing immediately loaded mandibular overdentures during a 1-year follow-up.

\section{Material and Methods}

\section{Experimental Design}

This study was a non-randomized controlled clinical trial. The participants were attended in the Department of Dentistry of the Federal University of Rio Grande do Norte (UFRN). The study was approved by the Ethics Committee of the institution (protocol \# 326/2011).

\section{Individuals}

The participants were bimaxillary complete edentulous patients treated with maxillary conventional complete dentures and mandibular 2-implant overdentures with 
bar-clip attachment system. The patients were divided into two groups and those presenting bone availability $\geq 13 \mathrm{~mm}$ were allowed to receive Morse Taper implants (Neodent). The patients with bone height from 11 to $13 \mathrm{~mm}$ were allowed to receive External Hexagon implants (Neodent). A total of 9 patients were treated with Morse Taper implants while the other 11 patients were restored with External Hexagon implants. Since 2 implants were inserted in each patient for fabrication of the mandibular overdentures, a total of 40 implants were evaluated in this study (18 MT and $22 \mathrm{EH}$ ). From the sample of the study, the sample power was calculated with a 95\% confidence interval and $80 \%$ test power in the software OpenEpi (15). Considering the difference between the means of peri-implant bone loss in both groups, the sample is able to detect statistically significant differences between the External Hexagon and Morse Taper implants for a minimum difference of $0.75 \mathrm{~mm}$.

\section{Treatment}

The old conventional complete dentures were replaced by new ones. In order to reach the maximum extension of the prostheses, functional impression was taken and the casts were mounted in bilateral balanced occlusion. After wearing the new dentures for 3 months, the mandibular conventional dentures were converted into immediately loaded implant-supported overdentures. For both groups, two implants Neodent ${ }^{\circledR}$ Titamax (Neodent; $3.75 \mathrm{~mm}$ in diameter; $11 \mathrm{~mm}$ in height) were inserted in the mandible. The External Hexagon implants were placed at alveolar crest level while the Morse Taper implants were inserted $2 \mathrm{~mm}$ below the alveolar crest. These protocols are established

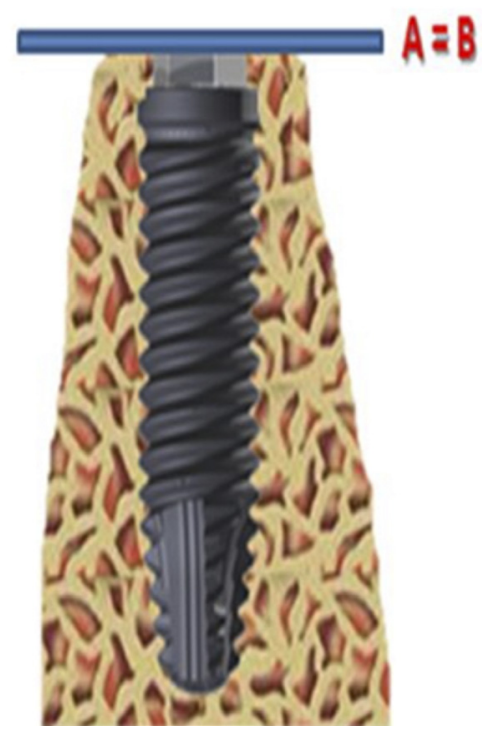

Figure 1. External Hexagon implant placed at the bone ridge level. Bone ridge level (A) similar to the implant platform level (B). Periimplant bone level is zero. by the implants' manufacturer (Neodent).

\section{Radiographic Analysis}

Periapical radiographs were taken for each implant placed in the mandible after insertion of the mandibular overdentures and following 12 months. For this, the parallelism technique was conducted using an occlusal positioner to standardize the film position and angulation of the x-ray axis (16). All radiographs were taken in the clinic of Prosthodontics of UFRN, using the same device for radiographic exam (Dabi Atlante, Spectro 70X Seletronic) with exposure time of $0.45 \mathrm{~s}$.

The periapical radiograph was taken using a resin device in which the rubber of the positioner was duplicated with polysiloxane silicone and the gap filled with acrylic resin to simulate the rubber bitten in the positioner. This device was inserted into the patient's mouth together with the positioner and a small portion of resin Duralay. The resin Duralay was used for bite registration to standardize a single positioning for radiographs taken immediately after overdentures insertion (T1) and following 12 months (T2). This device was fabricated for each implant.

The peri-implant bone level was assessed through digitalization and analysis of those radiographs in the software Corel DRAW X7. The measurement from the implant platform to the bone ridge at the mesial and distal surfaces was calculated at T1 and T2 (Figs. 1 and 2). The values of peri-implant bone level were assumed as positive when the bone ridge was above the implant platform and negative when the bone ridge was positioned below the platform. A single examiner, that did not

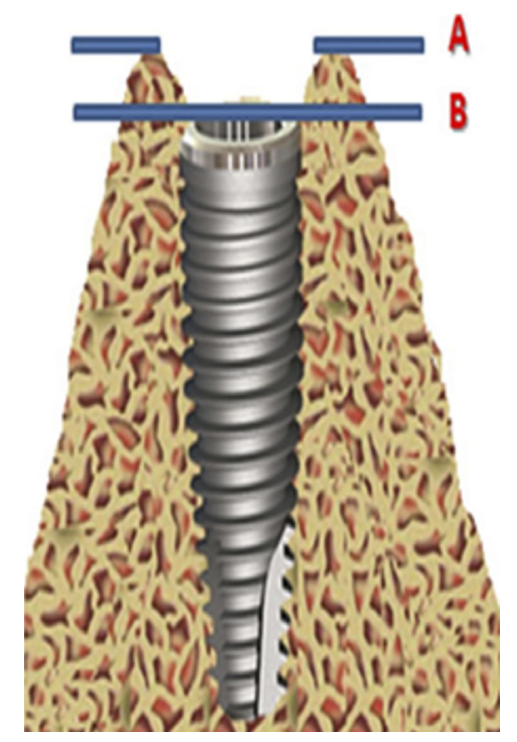

Figure 2. Morse Taper implant placed $2 \mathrm{~mm}$ below the bone ridge level. Peri-implant bone level corresponds to the measure between the bone ridge (A) and the implant platform (B). 
participate in the restoration process and blinded for the period of evaluation, conducted the radiographic analysis. This examiner was trained to identify what would be the implant platform and bone crest radiographically prior to analysis. The difference in values of bone level for each surface between the periods of evaluation was calculated. Then, the mean values at mesial and distal surfaces were obtained and used to calculate the peri-implant bone loss for each implant.

\section{Implants Success Rate}

The success of each implant was based on the specific criteria established in the literature (17). In this sense, the implants should be fixed during clinical trial; the radiograph should not present any radiolucent area at peri-implant region; and no signs and symptoms of pain, infection, neuropathy, paresthesia or damage of the mandibular canal should be present.

\section{Statistical Analysis}

Data analysis was conducted in the statistical software SPSS, version 20.0 for Windows. Data normality was assessed by Kolmogorov-Smirnov test. Since normal $\vec{s}$ distribution of data was not confirmed, non-parametric tests were conducted. Wilcoxon test was used to assess the differences in peri-implant bone level between the evaluations conducted immediately after insertion of mandibular overdentures and following 1 year within each group. For analysis of correlation between the groups and peri-implant bone loss, Mann-Whitney test was selected. All analyses were carried out at 5\% level of significance.

\section{Results}

A total of twenty patients (16 women and 4 men) wearing maxillary conventional complete dentures and mandibular 2-implant overdentures with bar-clip attachment system were evaluated in this study. The age ranged from 42 to 75 years, with mean age of $58.35( \pm 9.12)$ years. A total of 40 implants were evaluated (22 $\mathrm{EH}$ and 18 MT). The mean age was similar for both groups $(58.71 \pm 8.93$ for MT and $57.78 \pm 9.44$ for $\mathrm{EH}$ ).

For peri-implant bone level, the group MT showed no significant difference between the periods of evaluation ( $p=0.653$ ). In contrast, significant difference was found in the group EH $(p<0.001)$ (Table 1).

Comparing peri-implant bone loss between the groups, the results revealed greater bone loss with External Hexagon implants compared to the Morse Taper implants $(p=0.032)$ (Table 1). In general, mean bone loss was $0.85 \mathrm{~mm}( \pm 0.82)$ for $E H$ and $0.10 \mathrm{~mm}( \pm 1.0)$ for MT.

Considering the implants success, only one Morse Taper implant was lost during the 1-year follow-up. High success rate was found for both groups EH (100\%) and MT (94.4\%).

\section{Discussion}

This longitudinal non-randomized controlled trial aimed to evaluate the peri-implant bone loss and success rate of External Hexagon and Morse Taper implants in patients wearing mandibular overdentures during a prospective 1 -year follow-up. The patients in both groups were treated with immediately loaded 2-implant mandibular overdentures with bar-clip attachment system.

It's already established in the literature that a successful implant shows peri-implant bone loss up to $1.5 \mathrm{~mm}$ during the first year (17-19). In this study, a high success rate was found after 1 year for the External Hexagon (100\%) and Morse Taper (94\%) implants. This result is similar to previous studies for implants supporting overdentures under immediate and conventional loading $(3,4,20)$. The high success rate suggests reliability for treatment with immediately loaded overdentures using both External Hexagon and Morse Taper implants. One Morse Taper implant was lost during the first month of rehabilitation, suggesting that masticatory overloading has probably damaged the primary stability of the implant; which corresponds to the first key point for success of immediately loaded restoration (20).

For peri-implant bone loss, the general mean was $0.53 \mathrm{~mm}$, which is similar to previous studies evaluating overdentures under immediate or conventional loading

Table 1. Peri-implant bone level (mm) evaluated in External Hexagon and Morse Taper implants after insertion of mandibular overdenture (T1) and following 1 year (T2)

\begin{tabular}{|c|c|c|c|c|c|c|c|c|c|c|c|}
\hline & \multicolumn{5}{|c|}{ External Hexagon $(\mathrm{n}=22)$} & \multicolumn{5}{|c|}{ Morse Taper $(\mathrm{n}=17)$} & \multirow{2}{*}{$\mathrm{p}^{*}$} \\
\hline & Med & $\mathrm{Q}_{25}$ & $\mathrm{Q}_{75}$ & LI & LS & Med & $\mathrm{Q}_{25}$ & $\mathrm{Q}_{75}$ & LI & LS & \\
\hline $\mathrm{T} 1$ & -0.34 & -1.48 & 0.79 & -1.78 & 1.90 & 0.12 & -0.27 & 0.55 & -2.59 & 1.83 & \multirow{2}{*}{0.032} \\
\hline $\mathrm{T} 2$ & -1.28 & -1.98 & -0.31 & -2.63 & 1.68 & -0.73 & -1.42 & 1.81 & -2.14 & 2.54 & \\
\hline $\mathrm{p}^{* *}$ & & & $<0.001$ & & & & & 0.653 & & & \\
\hline
\end{tabular}

*Statistical significance between the groups (Man Whitney test). ${ }^{* *}$ Statistical significance in each group regarding the period of evaluation (Wilcoxon test). 
$(2,6,21)$. Comparing both groups, the mean bone loss was $0.85 \mathrm{~mm}$ for External Hexagon implants and $0.10 \mathrm{~mm}$ for Morse Taper implants. So, it was found greater peri-implant bone loss with External Hexagon implants after 1-year follow-up. Similarly, the literature evaluating the influence of joint design on bone resorption suggests that external joints cause greater peri-implant bone loss compared to internal joints (12-14).

Literature has also discussed about bone loss etiologies after loading of implants. The most frequent causes are surgical trauma, microgaps, peri-implantitis and immediate loading (21-23). The results of this study are probably related to the presence of microgaps between the External Hexagon implant and abutment, in contrast to the intimate matching observed between the Morse Taper components $(9,10)$. This accurate fit provides better sealing against bacterial microleakage and stability between implant and abutment, which may preserve the peri-implant tissues $(9,13)$.

The microgap at implant-abutment interface leads to biofilm accumulation and subsequent inflammation of the peri-implant tissue. Since the bacterial biofilm is a relevant etiological factor for peri-implant disease and bone resorption, External Hexagon implants might be associated with greater bone loss as observed in the present study (24). Furthermore, the tapered design of Morse Taper implants avoids micromovements in the surrounding bone under lateral stress and also reduces peri-implant bone loss in comparison to External Hexagon implants (10).

Although the External Hexagon implants have presented the greatest bone loss, the mean bone loss found in this study is within the acceptable level established by the literature after 1 year of implant placement (17). This result suggests that both External Hexagon and Morse Taper implants are safe for restoration with mandibular 2-implant overdentures under immediate loading. However, the Morse Taper implants are more suitable for those patients presenting previous resorbed ridge in order to maintain peri-implant bone level over time.

In the present study, peri-implant bone loss was assessed using periapical radiographs. This method is indicated to determine levels of peri-implant bone loss over time (25). Nevertheless, the periapical radiograph provides a two-dimensional image of a three-dimensional structure, allowing measurement only at mesial and distal surfaces (18). Since the buccal and lingual surfaces are not measured using this method, further studies using computed tomography are required to assess peri-implant bone loss with External Hexagon and Morse Taper implants in order to confirm the present results. The groups were not randomized because some individuals did not present bone availability $(\geq 13 \mathrm{~mm}$ ) for placement of Morse Taper implants, since this type of implant is placed $2 \mathrm{~mm}$ below the bone crest and height of the implants was $11 \mathrm{~mm}$. This limitation of the study requires further random studies comparing peri-implant bone loss with External Hexagon and Morse Taper implants to reduce bias.

As a result, it was found that a total of 39 implants was enough to reveal significant difference between the groups, since the difference between the means of periimplant bone loss was $0.75 \mathrm{~mm}$. According to the test power calculation, the significant difference between External Hexagon and Morse Taper groups would only appear if the difference between the means of peri-implant bone loss was at least $0.75 \mathrm{~mm}$ (15). In the present study, this difference between means was found. The sample size was small but in accordance with previous trials with similar purpose and methods $(1,24)$.

After 1-year follow-up, the clinical and radiographic data of this study suggest that a immediately loaded restoration with External Hexagon or Morse Taper implants preserves peri-implant hard tissues in comparison to the literature about restorations under conventional and immediate loading. Thus, this restoration design is indicated for treatment of patients requiring an implant-supported removable prosthesis. However, studies with greater sample size and longer follow-up are needed for a long-term comparison between the implant designs and to obtain more precise relationships between peri-implant health and longevity of the implants.

Comparing the levels of peri-implant bone loss during a 1-year follow-up, it was found significant peri-implant bone loss with External Hexagon implants in contrast to Morse Taper implants. Comparing peri-implant bone loss between the groups, greater bone loss was found with External Hexagon than Morse Taper implants.

\section{Resumo}

0 objetivo deste estudo foi avaliar a perda óssea peri-implantar de implantes Hexágono Externo (HE) e Cone Morse (CM) em usuários de sobredentaduras mandibulares com carga imediata por um período de acompanhamento de 1 ano. Este é um ensaio clínico controlado não randomizado que inclui $18 \mathrm{CM}$ e $22 \mathrm{HE}$. Radiografias periapicais foram obtidas na instalação das sobredentaduras e 1 ano após. A perda óssea peri-implante foi avaliada através da digitalização e análise das radiografias no software Corel DRAW X7. Para tal, a medição foi feita da plataforma dos implantes até a crista óssea nas faces mesiais e distais de cada implante. Os resultados mostraram alta taxa de sucesso nos grupos HE (100\%) e CM (94,4\%). Para os níveis ósseos peri-implantes, foi encontrada diferença significativa entre os grupos $(p=0,032)$ e maior perda óssea foi observada no grupo HE. Em média, a perda óssea foi de $0,85 \mathrm{~mm}( \pm 0,82)$ para $\mathrm{HE}$ e de $0,10 \mathrm{~mm}( \pm 1,0)$ para CM. Concluiu-se que uma maior perda óssea ocorreu no grupo HE em comparação com o grupo CM após um acompanhamento de 1 ano.

\section{References}

1. Meijer HJA, Raghoebar GM, Batenburg RH, Visser A, Vissink A. Mandibular overdentures supported by two or four endosseous 
implants: a 10-year clinical trial. Clin Oral Impl Res 2009;20:722-728.

2. Goodacre CJ, Bernal G, Rungcharassaeng K, Kan JY. Clinical complications with implants and implant prostheses. J Prosthet Dent 2003;90:121-132.

3. Borges TF, Mendes FA, de Oliveira TR, do Prado CJ, das Neves FD. Overdenture with immediate load: mastication and nutrition. Br J Nutr 2011;105:990-994.

4. Mangano C, Mangano FG, Shibli JA, Ricci M, Perrotti V, d'Avila S, et al.. Immediate loading of mandibular overdentures supported by unsplinted direct laser metal-forming implants: results from a 1-year prospective study. J Periodontol 2012;83:70-78.

5. Attard NJ, Zarb GA. Immediate and early implant loading protocols: a literature review of clinical studies. J Prosthet Dent 2005;94:242-258.

6. Cehreli MC, Uysa S, Akça K. Marginal bone level changes and prosthetic maintenance of mandibular overdentures supported by 2 implants: a 5-year randomized clinical trial. Clin Implant Dent Relat Res 2010;12:114-121.

7. Algraffee $\mathrm{H}$, Barumandi $\mathrm{F}$, Cascarini L. Peri-implantitis. $\mathrm{Br} \mathrm{J}$ Oral Maxillofac Surg 2012;50:689-694.

8. Esposito M, Hirsch JM, Lekholm U, Thomsen P. Biological factors contributing to failures of osseointegrated oral implants. (II). Etiopathogenesis. Eur J Oral Sci 1998;106:721-764.

9. Machado LS, Bonfante EA, Anchieta RB, Yamaguchi S, Coelho PG. Implant-abutment connection designs for anterior crowns: reliability and failure modes. Implant Dent 2013;22:540-545.

10. Almeida EO, Freitas AC Jr, Bonfante EA, Marotta L, Silva NR, Coelho PG. Mechanical testing of implant-supported anterior crowns with different implant/abutment connections. Int J Oral Maxillofac Implants 2013;28:103-108.

11. Schwarz F, Hegewald A, Becker J. Impact of implant-abutment connection and positioning of the machined collar/microgap on crestal bone level changes: a systematic review. Clin Oral Implants Res 2014;25:417-425.

12. Koo KT, Lee EJ, Kim JY, Seol YJ, Han JS, Kim TI, et al.. The effect of internal versus external abutment connection modes on crestal bone changes around dental implants: a radiographic analysis. J Periodontol 2012;83:1104-1109.

13. Peñarrocha-Diago MA, Flichy-Fernández AJ, Alonso-González R, Peñarrocha-Oltra D, Balaguer-Martínez J, Peñarrocha-Diago M. Influence of implant neck design and implant-abutment connection type on peri-implant health. Radiological study. Clin oral implants Res 2013;24:1192-200.
14. Castro DS, Araujo MA, Benfatti CA, Araujo C dos R, Piattelli A, Perrotti V et al.. Comparative histological and histomorphometrical evaluation of marginal bone resorption around external hexagon and Morse cone implants: an experimental study in dogs. Implant Dent 2014;23:270276.

15. Dean AG; Sullivan KM, Soe MM. OpenEpi: Open Source Epidemiologic Statistics for Public Health 2015. Available at: http://www.OpenEpi. com.

16. Roe $P$, Kan JY, Rungcharassaeng $K$, Lozada JL, Kleinman AS, Goodacre $\mathrm{CJ}$, et al.. Immediate loading of unsplinted implants in the anterior mandible for overdentures: a case series. Int J Oral Maxillofac Implants 2009;25:1028-1035

17. Albrektsson T, Zarb G, Worthington P, Eriksson AR. The long-term efficacy of currently used dental implants: A review and proposed criteria for success. Int J Oral Maxillofac Implants 1986;1:11-25.

18. Smith DE, Zarb G. Criteria for success of osseointegrated endosseous implants. J Prosthet Dent 1989;62:567-572.

19. Song DW, Lee DW, Kim CK, Park KH, Moon IS. Comparative analysis of peri-implant marginal bone loss based on microthread location: A 1-year prospective study after loading. J Periodontol 2009;80:19371944.

20. Nkenke $E$, Fenner M. Indications for immediate loading of implants and implant success. Clin Oral Implants Res 2006;17:19-34.

21. Geraets WG, Verheij HG, Wismeijer D, van der Stelt PF. Detecting bone loss along dental implants by subtraction of panoramic radiographs. Clin Oral Implants Res 2012;23:861-865.

22. Hermann JS, Buser D, Schenk RK, Higginbottom FL, Cochran DL. Biologic width around titanium implants. A physiologically formed and stable dimension over time. Clin Oral Implants Res 2000;11:1-11.

23. Oh TJ, Yoon J, Misch CE, Wang HL. The causes of early implant bone loss: Myth or science? J Periodontol 2002;73:322-333.

24. Ponzoni D, Gadotti RJ, Sartori IA, Liotto EM Jr. Digital radiographic evaluation of the level of alveolar bone crest in external hexagon implants submitted to 2 types of implant abutments under immediate loading. J Craniofac Surg 2011;22:2312-2317.

25. Lang NP, Berglundh T. Periimplant diseases: where are we now? Consensus of the Seventh European Workshop on Periodontology. J Clin Periodontol 2011;38:178-181. 